\title{
Employee motivational structure as a factor of organizational commitment
}

\author{
Irina Cheremisova ${ }^{1, *}$, Olga Suvorova $^{2}$ and Svetlana Sorokoumova ${ }^{3}$ \\ ${ }^{1}$ Academy of Law and Management of the Federal Penitentiary Service of Russia, Ryazan, 390000, \\ Russia \\ ${ }^{2}$ Nizhny Novgorod State Pedagogical University, Nizhny Novgorod, 603005, Russia \\ ${ }^{3}$ Novosibirsk Military Institute named after General of the Army I.K. Yakovlev of the National Guard \\ of the Russian Federation, Novosibirsk, st. Klyuch-Kamyshensky plateau, 6/2, 630114, Russia
}

\begin{abstract}
The article presents empirical findings of characteristics of the employee motivation structure of a manufacturing plant depending on the commitment level of employees. The authors used a complex approach to assessing the employee motivational structure. The diagnostic complex included research methods of employee satisfaction of needs, job satisfaction, personality focus, type of motivational structure. To study the organizational commitment of employees, the organizational commitment questionnaire of L. Porter was used. The number of respondents was 104 people, 51 people of them had a high level of commitment, 53 people - a low level. The empirical study revealed differences in the employee motivational structure depending on the level of their organizational commitment. Employees with a high organizational commitment level demonstrated a more mature and harmonious motivational structure: focus on the task, creative activity in the labour process and aiming at social usefulness; significantly higher satisfaction rates of social and interpersonal needs, needs for recognition and self-expression $(\mathrm{p}<0.01)$.
\end{abstract}

\section{Introduction}

Psychologists, sociologists and economists study different components of the problem of efficiency improvement of the organization and strengthening the competitiveness of the organization on the market of goods and services. Recently, much attention has been paid to the phenomenon of organizational commitment of employees as one of the key factors in efficiency improvement of the organization. In domestic science, studies of the organizational commitment phenomenon are still isolated and separated [1]-[6]. In scientific works of foreign scientists, the organizational commitment problem has found more complete and detailed reflection. However, there is no clear definition of the "organizational commitment" term. Some authors consider it another word for employee loyalty to the organization, identity with the organization. Other researchers clearly separate these concepts.

\footnotetext{
* Corresponding author: irinarusa@inbox.ru
} 
In substantiating the concept of organizational loyalty V. I. Dominyak [2] relies on studies of foreign authors who use the "organizational commitment" term. V. I. Dominyak [2] considers organizational loyalty as a socio-psychological pattern, including emotional (feelings and emotions in relation to the organization), cognitive (sharing and acceptance of organizational goals, values, norms, etc.) and behavioural (voluntary activity in the interest of the organization) components. However, the position of V. I. Dominyak [2] differs from most existing approaches. He excludes from the definition of organizational loyalty the intention to continue work in the organization. V. I. Dominyak [2] considers it important to separate the relation to the organization (attitude) and the behaviour of the employee. This understanding of organizational loyalty, according to V. I. Dominyak [2], allows expanding the range of loyalty persons considered. V. I. Dominyak [2] believes that potential and former employees can be included in this circle. V. I. Dominyak states that this will expand the boundaries of understanding the phenomenon of organizational loyalty by converging it with the concept of customer loyalty [2].

In this regard, the internal marketing, cross-functional coordination, coordinated efforts of various departments studies of foreign scientists are of interest. The researchers note that this will help to create the maximum attractiveness of the organization for employees. Internal marketing considers all employees as internal ones [7]-[9]. This implies a special practice of personnel management. Such management can ensure the satisfaction of internal customers with the personnel management model and coordinated interaction with colleagues [9].

Results of the study of Farzad et al. [8] showed that cross-functional coordination of different divisions and integration are most important for organizational commitment.

In addition, a number of authors use as synonyms the terms "corporate commitment" and "organizational commitment" [10-15].

Most researchers note that organizational commitment is related to job satisfaction, however, these phenomena are not identical $[2,16]$.

L. Porter is considered to be one of the key authors of the study of organizational commitment phenomenon [17]. L. Porter defines organizational commitment as the willingness of the employee to make a great effort in the interest of the organization, a strong desire to stay in the company, acceptance of its core goals and values [17].

The other most popular organizational commitment concept describes a three-component model [18, 19]. This organizational commitment model includes: emotional commitment (emotional attachment of the employee to the organization, identification with it, involvement); continued (current) commitment (employee awareness of the costs associated with his departure from the organization); normative component of commitment (employee awareness of obligations towards the organization).

The study of M. I. Magura presents the position that commitment reflects the patriotism of employees, dedication to the organization, commitment to its goals, willingness to give all their abilities, all their strength to achieve victory over competitors. In addition, organizational commitment is defined as psychological education, which includes a positive assessment by the employee of his stay in the organization, the intention to maintain his membership in it [20].

Paying attention to the concept of "fidelity or loyalty" A. O. Hirshman [21] defines it as a special attachment of the individual to the organization. He considers the active desire of the employee to change something in his organization as a dedication function.

Most researchers note that organizational commitment is related to job satisfaction, however, these phenomena are not identical [12, 16, 22, 23].

Is an International reputed journal that published research articles globally. All accepted papers should be formatted as per Journal Template. Be sure that Each author profile (min 100 word) along with photo should be included in the final paper/camera ready submission. 
It is be sure that contents of the paper are fine and satisfactory. Author (s) can make rectification in the final paper but after the final submission to the journal, rectification is not possible. In the formatted paper, volume no/ issue no will be in the right top corner of the paper. In the case of failure, the papers will be declined from the database of journal and publishing house. It is noted that: 1. Each author profile along with photo (min 100 word) has been included in the final paper. 2. Final paper is prepared as per journal the template. 3 . Contents of the paper are fine and satisfactory. Author (s) can make rectification in the final paper but after the final submission to the journal, rectification is not possible.

\section{Materials and methods}

The goal of our empirical study was to research the employee motivation structure of the production enterprise depending on the organizational commitment level.

The objectives of the study: to assess the organizational commitment level of employees; to study the employee motivation structure; to investigate the relationship between the commitment level of the employee to the organization and the type of motivation structure; to develop recommendations to improve the organizational commitment level of employees.

Methodologies used: Organizational Commitment Questionnaire of L. Porter [17]; diagnosis of satisfaction degree of basic needs by the method of paired comparisons of $\mathrm{V}$. V. Skvortsova [24]; test "Job Satisfaction" of V. A. Rozanova [24]; "Orientational Questionnaire Test" of V. Smeykal and M. Kucher [24]; "Diagnostics of Motivational Personality Structure" of V. E. Milman [24].

The survey was conducted at the production plant of "Silicate Plant No.1" JSC in Nizhny Novgorod. The technical staff of the enterprise - employees with secondary technical education took part in it. The number of respondents was 104. The median age of the respondents was 36 years. Women $-35 \%$, men $-65 \%$. The average length of service in the organization is 14 years, including: less than 1 year $-16 \%$; $1-3$ years $-20 \%$; $3-5$ years $22 \%$; 5-10 years $-28 \%$; more than 10 years $-14 \%$. Two divisions of the enterprise with similar material remuneration of employees (remuneration system) took part in the survey. The number of respondents in the first division (Group 1) was 51 people, in the second (Group 2) - 53 people. The anonymity of the study was observed during the survey.

The organizational commitment levels of employees of two enterprise divisions were surveyed at the first stage with the use of the Questionnaire of L. Porter [17]. The second stage was dedicated to the study and analysis of motivational factors of organizational commitment. The third stage included the presentation of our recommendations on increasing the organizational commitment level of the enterprise employees.

\section{Results and discussion}

The results of the study of organizational commitment in two divisions of the enterprise showed that the first group of respondents had a high commitment level (13.12), and the second group showed a low organizational commitment level (5.98). The organizational commitment index varies in the range from 3 to 15 , so in our case, we have almost a polar attitude of employees to the organization. This is important for our comparative study.

L. Porter defines organizational commitment as "identification of the individual with the organization, which means the acceptance of the organization values, desire to work for its good, desire to remain a member of the organization" [17, p. 604]. The first enterprise division showed the employees' high commitment. This manifests in the form of desire to serve the enterprise, to stay at the enterprise and to work hard for the benefit of the enterprise (Group 1). The division with a similar wage distribution exhibits a low organizational 
commitment index (Group 2). The differences are statistically significant by the MannWhitney U-criterion $(\mathrm{p}<0.01)$.

To study the motivational structure of employees in both groups, the methodology of assessing employee satisfaction of needs with the method of paired comparisons of V. V. Skvortsova was used. The satisfaction degree of five types of needs was studied: material needs, security and stability needs, social needs, recognition needs, self-expression needs.

The survey results of employee satisfaction of needs are presented in Table 1

Table 1. Satisfaction of needs depending on the organizational commitment level of the employee.

\begin{tabular}{|l|c|c|}
\hline \multicolumn{1}{|c|}{$\begin{array}{c}\text { Category of } \\
\text { needs }\end{array}$} & $\begin{array}{c}\text { Group 1 (high organizational } \\
\text { commitment level) }\end{array}$ & $\begin{array}{c}\text { Group 2 } \\
\text { (low organizational commitment level) }\end{array}$ \\
\hline Material needs & 14.2 & 12.1 \\
\cline { 2 - 3 } & satisfaction zone & satisfaction zone \\
\hline \multirow{2}{*}{ Security needs } & 28.0 & 37.2 \\
\cline { 2 - 3 } & dissatisfaction zone & dissatisfaction zone \\
\hline Social needs & 15.1 & 28.2 \\
\cline { 2 - 3 } & satisfaction zone & dissatisfaction zone \\
\hline $\begin{array}{l}\text { Recognition } \\
\text { needs }\end{array}$ & 15.9 & partial satisfaction zone \\
\hline $\begin{array}{l}\text { Self-expression } \\
\text { needs }\end{array}$ & partial satisfaction zone & 26.7 \\
\cline { 2 - 3 } & 10.8 & dissatisfaction zone \\
\hline
\end{tabular}

The results indicated in Table 1 show that the first group with a higher commitment level has the security and stability needs in the dissatisfaction zone (28.0), and the dissatisfaction zone of the second group includes such needs as: self-expression needs (26.7), social needs (28.2) and security needs (37.2). The analysis shows that in the group with a high commitment level, social needs (15.1) and the needs for self-expression (10.8) are located in the satisfaction zone. This may reflect a good socio-psychological climate of the division.

The second group in the satisfaction zone includes only material need (12.1), but there are also interpersonal tensions (28.2) and dissatisfaction with social and self-expression needs. This may reflect a lack of recognition of the employee merits by the manager and colleagues. It is obvious that satisfaction with their job and effective employee activities are possible when the employee is focused on the content of work and works in a favourable environment, where interpersonal relationships are positive. In this case, there may be obvious career prospects. In such conditions, the employee will work with dedication, hold on to work in the organization, not looking for another job. Thus, it can be concluded that satisfaction with the employee social needs and satisfaction with self-expression needs reveal an indirect correlation with the employee commitment to the organization. The differences are statistically significant by the Mann-Whitney U-criterion $(p<0.01)$.

To confirm the conjugacy of organizational commitment and employee satisfaction with work in general, microclimatic working conditions, the content of activities and relationships with the manager and colleagues, the test "Job Satisfaction" of V. A. Rosanova was used.

Table 2. Job satisfaction depending on the organizational commitment level of the employee.

\begin{tabular}{|c|c|c|}
\hline $\begin{array}{c}\text { Scale of job } \\
\text { satisfaction of the } \\
\text { employees }\end{array}$ & $\begin{array}{c}\text { Group 1 } \\
\text { (high organizational commitment } \\
\text { level) }\end{array}$ & $\begin{array}{c}\text { Group 2 } \\
\text { (low organizational commitment } \\
\text { level) }\end{array}$ \\
\hline $\begin{array}{c}\text { quite satisfied 15-20 } \\
\text { points }\end{array}$ & - & - \\
\hline $\begin{array}{c}\text { Satisfied 21-32 } \\
\text { points }\end{array}$ & 22 & - \\
\hline $\begin{array}{c}\text { rather dissatisfied } \\
\text { 33-44 points }\end{array}$ & - & 32.5 \\
\hline
\end{tabular}




\begin{tabular}{|c|c|c|}
\hline $\begin{array}{c}\text { not satisfied } 45-60 \\
\text { points }\end{array}$ & - & - \\
\hline $\begin{array}{c}\text { highly dissatisfied } \\
\text { more than 60 points }\end{array}$ & - & - \\
\hline
\end{tabular}

Table 2 confirms the hypothesis that the group with a high commitment level is satisfied with the work in general (22), while the second group of respondents shows incomplete job satisfaction. That is, employee job satisfaction can also be considered as an indicator of commitment level. Satisfaction is considered in psychology as an indicator of the realization of individual needs. This confirms the link between the employee's commitment to the organization and the satisfaction with his/her social and self-expression needs. It was demonstrated in Table 1.

Thus, it can be stated that the motivational factor of satisfaction in the first group of respondents has positive indicators, the second group of respondents has lower indicators of job satisfaction, satisfaction with the nature of interpersonal relationships, satisfaction with the realization of self-expression needs, needs for recognition. We believe that the internal motivation to work decreases for this reason. External motivation (for example, wage level) cannot replace internal motivation for long. As a result, the organizational commitment level of employees decreases.

Research of professional personality focus of the employee was carried out in two groups with the use of "Orientational Questionnaire Test" of V. Smeykal and M. Kucher. Professional personality focus of the employee includes the following types of relations: the relation of the person to himself, the relation of the person to others and the relation of the person to work. Each person in his/her motivational structure presents all three types of relationships, but their proportion is different. Perhaps the dominance of "focus on yourself" or "focus on the job" or "focus on interaction with other people." People with "focus on the job", "on the task" are the most productive in work. The results of personality focus of employees of two groups depending on the organizational commitment level are presented in Table 3.

Table 3. Intra-group focus depending on the organizational commitment level of the employee.

\begin{tabular}{|c|c|c|}
\hline $\begin{array}{c}\text { Focus type of } \\
\text { the employee }\end{array}$ & $\begin{array}{c}\text { Group 1 (high organizational } \\
\text { commitment level) }\end{array}$ & $\begin{array}{c}\text { Group 2 } \\
\text { (low organizational commitment level) }\end{array}$ \\
\hline $\begin{array}{c}\text { Focus on } \\
\text { yourself }\end{array}$ & 11.0 & 5.0 \\
\hline $\begin{array}{c}\text { Focus on } \\
\text { interaction }\end{array}$ & 4.3 & 13.0 \\
\hline $\begin{array}{c}\text { Focus on the } \\
\text { task }\end{array}$ & 12.0 & 9.0 \\
\hline
\end{tabular}

The results presented in Table 3 show that employees from the first group of respondents demonstrated focus "on the task" (12.0/9.0) and "on yourself" (11.0/5.0) in a greater degree than employees from the second group. This testifies to aspiration of employees for the realization of goals and solution of tasks in professional activity process. It can also indicate the severity of egocentric tendencies, aspirations for personal well-being, prestige, the satisfaction of their desires.

In addition, employees from the first group (1) have a high degree of satisfaction with social needs and self-expression (Table 1). This may indicate that job satisfaction is related to creative work and collaboration in the workplace, rather than direct interpersonal communication. The differences are statistically significant by the Mann-Whitney Ucriterion $(\mathrm{p}<0.01)$.

At the same time, the focus on "interaction" dominates in the second group with a lower commitment level. It can be assumed that social needs are not sufficiently satisfied in this 
group of respondents, they have expressed the need for communication with other people, good relations with others, what is confirmed by Table 1. At the same time, the content of the work and its results go into the background. This makes the group less productive.

Finally, the motivational structure of employees depending on the organizational commitment level was investigated. The motivational structure of the employee personality has two types of motivation (according to V. E. Milman): productive and consuming. By results of the research on "Diagnostics of Motivational Personality Structure" of V. E. Milman some stable trends of personality were revealed: general and creative activity, desire to communicate, to ensure comfort. On the basis of all the answers, the judgment is made about the working (business) and customary personality focus. These results are presented in Table 4.

Table 4. Employee motivational structure depending on their organizational commitment level.

\begin{tabular}{|c|c|c|}
\hline $\begin{array}{c}\text { Motivational } \\
\text { factor }\end{array}$ & $\begin{array}{c}\text { Group 1 } \\
\text { (high organizational commitment level) }\end{array}$ & $\begin{array}{c}\text { Group 2 } \\
\text { (low organizational } \\
\text { commitment level) }\end{array}$ \\
\hline \multicolumn{2}{|c|}{ The customary personality focus } \\
\hline Life-support & 13.4 & 16.3 \\
\hline Comfort & 12.0 & 15.1 \\
\hline Social status & 10.3 & 13.3 \\
\hline Communication & 11.2 & 16.1 \\
\hline \multicolumn{2}{|c|}{ Working (business) personality focus } \\
\hline General activity & 13.3 & 15.1 \\
\hline Creative activity & 18.9 & 15.8 \\
\hline Social usefulness & 16.1 & 11.2 \\
\hline
\end{tabular}

Table 4 shows that creative work with a decent material component and social usefulness are important for the respondents of the first group. The respondents of the second group have a pronounced need for communication, material support and decent social status. In general, we see that among the employees with a high organizational commitment level (Group 1) "working (business) personality focus" is expressed to a greater extent than in Group 2 with lower organizational commitment level.

\section{Conclusion}

Thus, our study revealed the relationship between characteristics of the motivational structure of the production enterprise employees, depending on their organizational commitment level.

Employees of enterprise divisions with a higher commitment level demonstrate, above all, satisfaction with social needs and needs for self-expression, as well as job satisfaction in general. The satisfaction state allows to fully focus on solving work problems: focus on the task (12.0/9.0) and focus on yourself (11.0/5.0). These rates are higher in comparison with the group of employees with a low commitment level. The relationship of job satisfaction of this group with "focus on the job, the task", creative activity and cooperation in the workplace.

Employees of enterprise divisions with a lower commitment level demonstrate dissatisfaction with social needs and needs for self-expression. The motivational structure of the employees with a low commitment level reveals a "customary motivational profile" and a pronounced focus on interaction: needs for intra-group communication and recognition from the management, self-expression needs, needs for a decent social status. The results of the study showed that this leads to a decrease in the attractiveness of the organization for employees. 
The motivational structure of the employees with a high commitment level reveals maturity, harmony, focus on the task, creative activity in the labour process and desire for social usefulness. Such a group creates a healthy psychological atmosphere, is aimed at productivity, cooperation, benefits of the organization, is devoid of difficulties of contact communication and positively evaluates its stay in the organization.

\section{References}

1. V.V. Ageikina, Socio-psychological mechanisms for the development of organizational staff commitment. Dissertations for the degree of candidate of psychological sciences (Moscow, 2008)

2. V. Dominyak, Account Manager 4, 34-40 (2006)

3. S.A. Lipatov, World of Psychology 2, 142-148 (2004)

4. A. Lovakov, S. Lipatov, Psychology. Journal of the Higher School of Economics 8(2), 69-80 (2011)

5. G.A. Monusova, Russian Management Journal 29.13(4), 29-50 (2015)

6. E.Yu. Chernyakevich, Organization's commitment as a value-moral attitude of the personality. Thesis for the degree of candidate of psychological sciences (St. Petersburg, 2010)

7. M. Abzari, H. Ghorbani, F.A. Madani, Iran International Journal of Marketing Studies 3(1), 147-155 (2011)

8. A. Farzad, N. Nahavandi, \& A. Caruana, American Journal of Applied Sciences 5(11), 1480-1486 (2008)

9. S. Kusluvan, Ilhan, I. Kusluvan, L. Buruk, Cornell Hospitality Quarterly 51, 171-214 (2010)

10. J. Lincoln, A. Kalleberg, Industrial and Labor Relations Review 50(1), 39-59 (1996)

11. J. Lincoln, A. Kalleberg, Culture, control and commitment: a study of work organization and work attitudes in the United States and Japan (Cambridge Univ. Press, New York, 1990)

12. C. Mottaz, Human Relations 41(6), 467-482 (1988)

13. D. Gallie, European Sociological Review 23(3), 279-293 (2007)

14. C. Hult, S. Svallfors, European Sociological Review 18(3), 315-331 (2002)

15. E. Wasmer, The economics of Prozac: do employees really gain from strong employment protection? (World Bank Data, 2006) http://data.worldbank.org/indicator/NY.GDP.PCAP.CD

16. M. Magura, The commitment of the workers of their organization. Abstract of dissertation for the degree of candidate of psychological sciences (Moscow State University, M., 1999)

17. L. Porter, R. Steers, R. Mowday, P. Boulian, Journal of Applied Psychology 59(5), 603609 (1974)

18. J.P. Meyer, and N.J. Allen, Journal of Applied Psychology 69, 372-8 (1984)

19. J.P. Meyer, N.J. Allen, C.A. Smith, Journal of Applied Psychology 78, 538-551 (1993)

20. M. Magura, M. Kurbatov, Human Resource Management, 13-14 (2007)

21. A.O. Hirschman, Exit, voice and loyalty: a reaction to the decline of firms, org. and states (New publishing house, M., 2009) 
22. R. Snir, International Journal of Business and Social Science 2(16), 271-278 (2011)

23. P. Warr, Journal of Occupational Psychology 55, 297-312 (1982)

24. L.A. Vereshchagina, Personnel psychology: needs, motivation and values (Humanitarian Center, Kharkiv, 2012) 